\title{
Sri Lanka and Greco-Roman Maritime Trade Relations
}

\author{
Katugampola $\mathrm{M}^{1}$, Munasinghe D.S.A ${ }^{1 *}$, Nanayakkara $\mathrm{K}^{2}$, Fernando D.C.V ${ }^{3}$, Jayathilake K.K.P.M ${ }^{4}$ \\ $1^{*, 2,4}$ Department of Archaeology, University of Kelaniya, Sri Lanka. \\ ${ }^{3}$ Image Art \& Drama \& Theatre Unit, Department of Fine Art, University of Kelaniya, Sri Lanka. \\ DOI: 10.29322/IJSRP.11.07.2021.p11590 \\ http://dx.doi.org/10.29322/IJSRP.11.07.2021.p11590
}

\begin{abstract}
Sri Lanka had maritime trade relations even in the $6^{\text {th }}$ century $\mathrm{BC}$ and we had famous naval ports used for maritime trade especially for maritime 'Silk Road' used by people who were in Greco-Roman, China, India, Persia for their foreign trade. Therefore, Sri Lanka was able to make new economic relationships- In this study, we mainly focused on Sri Lankan maritime trade relationship with Greco-Roman. Our research problem is, what was the trade relationship between Sri Lanka and Greco-Roman?. Our objective is to identify the importance of Sri Lanka along with the GrecoRoman trade. This study was conducted under the qualitative research method using a library survey. From these three sources Literary sources, especially foreign texts have many records about Sri Lanka and Greco-Roman trade. Some of those authors were Cosmos, Pliny, Ptolemy and Strabo. Some archaeological evidence was found from ports like Mahathittha, Godawaya and Kingdoms like Anuradhapura, Polonnaruwa. The main archaeological evidence is Roman and Indo-Roman coins for the trade relationship between Sri Lanka and Greco-Roman. Certain Indian factors were also important in conducting this research because Sri Lankan trade had a close relationship with the Indian trade also. From this research we understood that there was an internal transport system in Sri Lanka, Roman trade was spread many places in Sri Lanka, in some times India and Persia acted as intermediaries between Sri Lanka and Greco-Roman trade and the main point we identified was, Sri Lanka was a core in the ancient trade system and by the fifth century AD, Sri Lanka was one of the main trade centres in the Indian Ocean.
\end{abstract}

Keywords: Sri Lanka, Greco-Roman, Maritime Trade, Relation, Coins

\section{Introduction}

The Mahavamsa has evidence that Sri Lanka has been engaged in foreign trade since pre-Cristian times as an example the Mahavamsa mentions the naval merchants who were eaten by Kuweni.[37] It seems that Sri Lanka had maritime trade relations even in the $6^{\text {th }}$ century BC. Also, we had famous naval ports used for maritime trade such as Gokanna, Mahathittha, Jambukola-Pattana \& Godawaya etc.[13) In ancient times there was an overland route called 'Silk Road' and is used by people who were in GrecoRoman, China, India, Persia for their foreign trade.[05][27]
After many years people made sailing vessels and merchants used them for their foreign trade. And they found a new marine route from China to Europe through the Indian Ocean. With the discovery of this road, Sri Lanka, which had been isolated in the Indian Ocean until then, began to open up to the world. Because of that Sri Lanka made new political, cultural, economic, devotional and social relationships with many countries.[31] Those economic relationships were mainly based on commercial activities. From Sri Lanka Archaeologists found much evidence that Sri Lanka had strong maritime trade relationships with countries such as India, China, Persia, Thailand, Myanmar, Greco-Roman etc. In this article, we mainly focused on Sri Lanka maritime trade relationship with Greco-Roman. This study was conducted to understand the trade relationship between Sri Lanka and Greco-Roman. And our objective is to identify the importance of Sri Lanka along with the Greco-Roman trade. Our research problem was, what was the trade relationship between Sri Lanka and Greco-Roman.

\section{Methodology}

The research was conducted from a Cultural-historical perspective under a qualitative method as a library survey. In the library survey, We referred to field reports, excavation reports, textbooks, journal articles, websites and newspapers. For web sources, web sites which published high standard academic research papers like "Jstor, Academia, Research Gate, and Google scholars" and website of international high ranked universities, National Universities and Archives.

\section{Results and Discussion}

There is some literature evidence that Sri Lanka had a maritime trade relationship with Greco-Roman. According to Mahavamsa, Greeks was the first Europeans who came to Sri Lanka and in Mahavamsa they were mentioned as 'Yona'.[44] The ancient Greek name for Sri Lanka was 'Taprobane'.[01][26][31][30][40][43][45][52][53][57]Beside s 'Taprobane' some Greek authors used 'Palaisimoundou', 'Salike' and 'Sieladiba' names for Sri Lanka.[57] Simply, Taprobane means 'copper coast' that gives a similar word for 'Thambapanni'. Cosmos used 'Taprobane' in his writings. Ptolemy used both 'Taprobane' and 'Palaisimoundou' in his 
writings and Pliny described 'Palaisimoundou' as a city near Kudiramle Harbour.[26][53][57]

Greek Captain of Great Alexander's Navy called Onecicritus of Astypaleia wrote about Sri Lanka, and Europeans got to know about this country from that. He wrote that Sri Lanka traded spices and elephants in his records.[57] The first Latin author to mention Sri Lanka was the poet Ovid, and he wrote there is a country called Taprobane in the Indian Ocean.[38][43] Eratosthenes's Geographka book contains Sri Lankan trade had an honourable position among Western countries at Before Christ period. Also, he recorded that Sri Lanka had better ships for trade. [57] Strabo the Greek Geographer also wrote about Sri Lankan cinnamon. Ptolemy (100-170 AD) who drew a world map and the map of Taprobane wrote about Sri Lanka in his records.[09] He mentioned the Sri Lankan trade of pearls, transparent stones, muslins, tortoise shells, rice, honey, ginger, beryl and other metals as well as elephants and tigers. According to Strabo these goods were brought to the Indian market and Greek merchants didn't come directly to Sri Lanka, but India and bought them.[52][34] From Ptolemy's maps,(Figure 01)[31] we can assume Sri Lanka trade had a great place among other countries in contemporary society, and it was quite famous among foreigners in the second century AD.

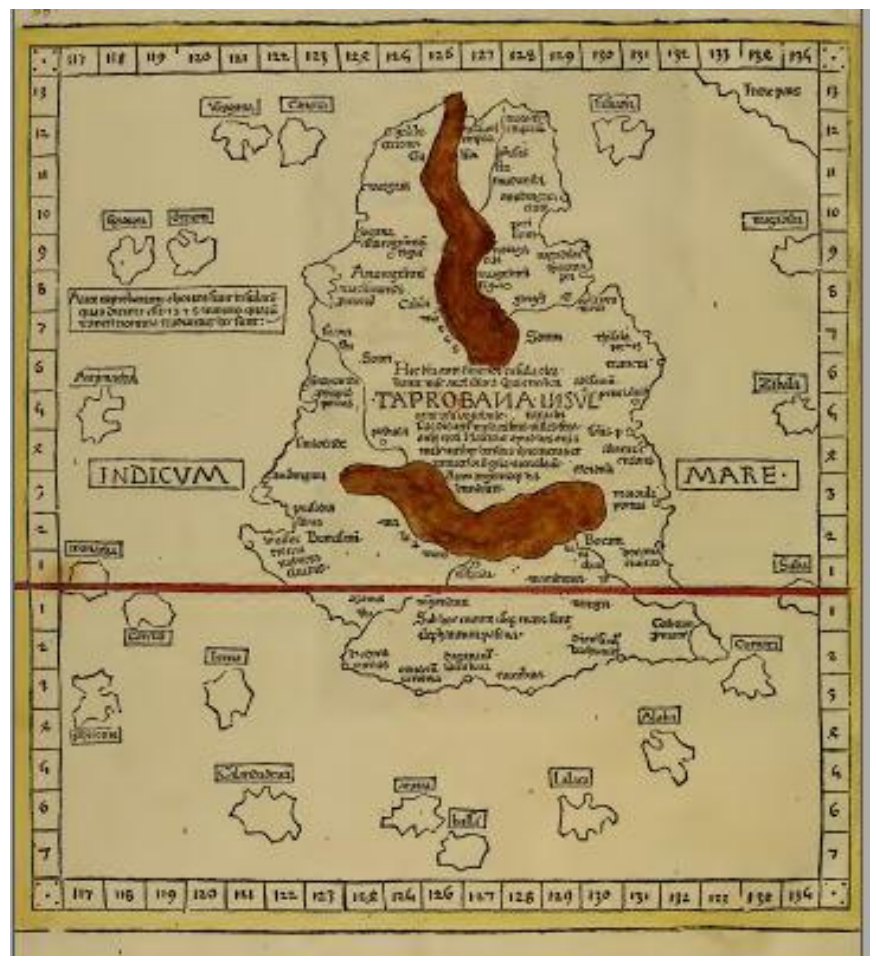

1 pavālajālami kāretvā ta khipāpiya cetiyē - sovanṇayāni padumāni cakkamattāni sandhisu'In Pali

2 Pliny records a storv (VI, 84) about an unnamed libertus of Annius Plocamus, a farmer

of the Nlaris Rubri uectigal :- Nobis diligentior notitia Claudi principatu contigit lcgatis ctiam ex ea insula [i.e. Ceylon].id-cctis. id acciclit hoc moclo : Anni Plocami, qui Maris ltubri vectigal a fisco redemerat, libertus circa Aral iam navigans aquilonibus raptus praetcr Carmaniam, xv die IJippu ros portum cius invcctus, laospitali regis clcmentia sex mensum tcmpore inbutus adloquio pcrcontanti postea narravit Rom<inos ct Cacsarcm. mirum in modum in auditis iustitiam ille suspcxit, quod pari ponders denarii csscnt in captiva pecunia, cum This publication is licensed under Creative Commons Attribution CC BY.

http://dx.doi.org/10.29322/IJSRP.11.07.2021.p11590
Megasthenes, the Greek Ambassador was in India, the Chandragupta Maurya's royal council wrote about Sri Lanka in his records. A Greek Christian priest named Cosmos Indicopleustes wrote about Sri Lanka in his book named 'Christian Topography' that heard from a merchant who had trade relations with this country.[20][51][38] As his records, Sri Lanka was recognized as 'Taprobane' by Greeks, and there were many merchant ships from China, India, Persia, Ethiopia in our ports. Speciality is, the informer of Cosmos's was a Greek merchant named 'Sopatrus' who had a trade relationship with Sri Lanka [38][57] And that was sixth century AD. According to Cosmos, Elephants were the main export of Sri Lanka, and Sri Lanka imported silk, Clove and Sandalwood[57]. He mentioned a stone called Hyacinth that Sri Lanka was export. But he didn't describe it. Some Greek and Rome writers mentioned precious stones, metals, pearls, muslins, ivory and tortoise shells in their records.[52] An unknown author of the book of 'Periplus Maris Erythraei' who was himself a merchant described Sri Lanka's rich trade such as pearls, gems, muslins and tortoise shells.[30][32] Among gems, Rube and Ceylon Sapphire were the famous and valuable gems in the period of the Roman Empire. According to Cosmos, besides Greeks Sri Lanka had a trade relationship with Rome also.

Pliny the Italian, wrote a book entitled 'Natural History' based on information obtained from delegations from Sri Lanka to Rome.[22][23] According to Pliny Sri Lanka had a trade relationship with Rome since first century AD. And he described the Rome trade relationship with Sri Lanka during the region of Claudius in Rome. According to Wansaththappakasini, at that time (King Bhathikabhaya's period) Sri Lankan merchants went to Rome as trade delegations and they brought beads that decorated Ruwanweli Stupa when they return.[25] In Wansaththappakasini it mentioned in pali as "pavālajālam kāretvā ta khipāpiya cetiyē - sovanṇayāni padumāni cakkamattāni sandhisu"1.[50] These merchants went to Rome with a Roman sailor named Annius Plocamus who accidentally came to Sri Lanka.[24][45][57] From this information, we can understand that Sri Lanka made a trade relationship with Rome at that time. And in Pliny's records, he mentioned the arrival of the embassy from Sri Lanka to Rome named 'Rachias' (possibly for Raja, king) during the period of Claudius who reigned from 41 to $54 \mathrm{AD} .^{2}$ $[03][38][39][04]^{3}$ This evidence shows the connection between ancient Sri Lanka and Rome.

diversac imagines indicarent a pluribus factos. et hoc maxime sollicit.itus ad amicitiam legatos quattuor misit principc eorum ltachia.

3 From Pliny the Elder's Natural History, we learn that: “[...] during the principate of Claudius, [...] an embassy actually came to Rome from the island of [Sri Lanka]. The circumstances were as follows: Annius Plocamus had obtained a contract from the Treasury to collect the taxes from the Red Sea; a freedman of his while sailing round Arabia was carried by gales [... and ] after a fortnight made the harbour of Hippuri in [Sri Lanka], where he was entertained with kind hospitality by the king, and in a period of six months acquired a thorough knowledge of the language; and afterwards in reply to the king's enquiries he gave him an account of the Romans and their emperor. The king among all that he heard was remarkably struck with 
Figure 01: Ptolemy's maps, Cosmographia: Ptolemy, 2nd cent. [31]

According to Procopius Persian and Ethiopian merchant ships anchored at the ports of Kirinda and Godapawatha until the arrival of merchandise, including silk, from the East. He further states that Chinese silk was brought to Rome by Persian merchants and that the Persians obtained the fabric from Sri Lanka.[25] This shows that Sri Lanka was an important trading centre for the sale of merchandise in the East and South-East to the Western Greek and Roman states. [27][57]

Large quantities of raw materials such as copper, glass, lead and tin were got demand in Sri Lanka. Also, Roman traders were interested in gemstones, fabrics, corals and mineral powders like antimony and sulfide. Iron was also very famous in Roman trade according to Pliny.[35]

There is some archaeological evidence about the GrecoRoman trade with Sri Lanka. But that information connected to India also. India found some evidence of Roman trade from Arikamedu.[07] Excavations conducted 1941 - 1950 period of time in there, archaeologists found wine jars, ceramic lamps and unguentaria, cups and plates of terra sigillata, glass bowls, blue glazed faience and from 1989 - 1992 period[06] archaeologists found a slipped Roman ware.[08][46][47][48][63] Some artefacts found from Godawaya are somewhat similar to artefacts found from Arikamedu and Pattanam.[14][15][49] Archaeologists found many Indo- Roman coins from private lands and paddy fields near the Walawe riverbank.[28] This site is very close to the Godawaya port and because of that, we can assume, merchants used internal transport in the Walawe river. From the investigation in Godawaya port, Archaeologists found an industrial powerhouse, and Archaeologists believed that the powerhouse was used for iron production that was mentioned in Greek and Roman texts about exported iron and steel along with India.[35]

A fragment of glass from the Eastern Mediterranean dating to the $1^{\text {st }}$ century BCE along with a few late Roman coins dating to the $5^{\text {th }}$ century $\mathrm{CE}$ was found from the most extensive archaeological site of Sri Lanka which is the initial site of Anuradhapura, that dated from $800 \mathrm{BCE}$ to 1100 CE.[42][18][19] Also from an excavation in Tissamaharama found foreign material such as Roman amphorae and Islamic glazed wares.[11][12][42][61][62] And some evidence was found from the Mantai excavation also.[05][60][63]

From pre-Christian times, Mantai was used as a trade centre between East and West. In the early times, Mantai Port was known as 'Mahathiththa', 'Mathota', 'Manthota' and 'Manthottam' in Tamil. [05][60][63] From Mantai

admiration for Roman honesty, on the ground that among the money found on the captive the denarii were all equal in weight, although the various figures on them showed that they had been coined by several emperors. This strongly attracted his This publication is licensed under Creative Commons Attribution CC BY.

http://dx.doi.org/10.29322/IJSRP.11.07.2021.p11590
Excavations Archaeologists found much evidence regarding foreign trade. They were found in pottery, Ceramics, Coins, Medals, Beads, Glass, Plant remains etc.[60] Potteries and Ceramics that has Chinese, West Asian and European origin were found from the site. Some Chinese ceramics belong to the Tang dynasty found from Mantai is representing the trade relationship with Chinese Empire in the ninth century. Most glasses found from Mantai belonged to the early Islamic period in the Middle East and some glass bangles belong to India. A mosaic cane bead found from the site belongs to the Roman world and from the same layer archaeologists were found a dull-white glass bangle which assumed probably imported from Rome.[60] Also, a sky blue glass core over which three stripes of compound yellow and white glass were found from the site that manufactured in Rome, and it is a very rare bead found from Asia.[60] According to Carswell and others, Corals was an important trade item with Rome, and they were found some evidence regarding it.[60]

Plant remains like phytoliths, wheat chaffs were found from this site. As an example, archaeologists were found grapes from the site, and they assumed it was coming from West Asia as a luxury product, Although tropical countries like Sri Lanka can't grow grapes.[65] Also, evidence about the spices trade was found in Mantai. Especially evidence about the black pepper trade between Sri Lanka and the Western world had found. According to Banham \& others black pepper shipped from Indian ports and grown in the wet zone of Sri Lanka, thus its native place was the Western Ghats in South-west India, and by the middle of the first millennium AD, Mantai was a marketplace for our wild pepper.[65] And there were historical records about the pepper trade between India and Rome, accordingly, we can say Sri Lanka also had a pepper trade relationship with Roman Empire.

Goods that were exported from Sri Lanka to Rome, gained Gold coins for Sri Lanka. After some time, Sri Lanka made coins the same as Rome from copper and used them in their day-to-day transactions. Archaeologists think that's why Roman coins are found in many places in Sri Lanka. According to Codrington, Rome coins found from Hambantota, Tissamaharama, Mannar, Galle, Matara, Jaffna, Polonnaruwa, Anuradhapura, Puttalam, Mantai, Anuradhapura, Kelaniya, Badulla, Mihintale, Sigiriya, Kandy, Kalpitiya, Colombo, Kalmunai, Kurunegala, Tissamaharama etc.[10][11][17][55] Codrington had mentioned the names of the kings and emprores who issued the coins in his records and they were Augustus (43 BC-14 AD), Tiberius (10 BC-35 AD), Claudius (41 AD-54 AD), Vespasian (70 AD-79 AD), Domitian (72 AD-96 AD), Hadrian (117 AD-138 AD), Faustina the Elder (141 AD), Lucius Verius (161 AD-169 AD), Julia Domna (217 AD), Geta (209 AD-212 AD), Elagabalus (218 AD-222 AD), Julia Mammaea (235 AD), Maximian I (235 AD-238 AD), Philp the Elder (244 AD-249 AD),

friendship, and he sent four envoys, the chief of whom was Rachias [possibly for Raja, king]." 
Pontumus (256 AD-267 AD), Tetricus the Elder (268 AD- 273

AD), Diocletian (284 AD-305 AD), Maximian II (292 AD-305

AD), Maximin II (308 AD-313 AD), Maxentus II (306 AD-

312 AD), Licinus I (307 AD-324 AD), Constantaine the Grate (306 AD-337 AD), Helena (328 AD), Fausta (326 AD), Crispus (317 AD-326 AD), Constattine II (317 AD), Constans I (333 AD), Constantius II (323 AD), Constantius Gallus (351 AD-354 AD), Julian (355 AD-360 AD), Valentinian (364 AD375 AD), Valens (364 AD-378 AD), Gratian (375 AD-383 AD), Valentinian II (375 AD-392 AD), Theodosius (379 AD395 AD), Aelia Flaccilla (388 AD), Victor(383 AD-388 AD), Honorius (394 AD-423 AD), Arcadius (395 AD-408 AD), Aelia Eudoxia, (395 AD-404 AD), Theodosius II (408 AD-450 AD),I Marcian (450 AD-457 AD),Anastasius (491 AD-518 AD), Heraclius I (613 AD-641 AD) and Constantine XIII (1059 AD- 1067 AD).[17][41]

The speciality was the same coins found from Sri Lankan sites were found from South India also.[64][65] This information proves that Sri Lanka and India had a trade connection with Rome. Because of some Roman coins found from inland locations, we can believe that Roman trade also spread in those areas. All the published and unpublished Late Roman Bronze coins and their so-called 'Indo-Roman' imitations found from Sri Lanka are more than 200 000.[11] Most of those imitation coins were made from copper.

According to Bopearachchi and Wickremesinghe, Roman coin hoards contained Roman and imitation coins were reported from Baragama (about 30 000), Hungama (about 20 000) and money boxes from Ridiyagama and Tissamaharama.[11] From Ridiyagama excavation conducted in 1995, found an ancient settlement. From there archaeologists were found coins from some countries including Rome coins, and they were assumed Ridiyagama was a trade centre in contemporary days because it is located near to the famous Godawaya port. Rome coins made of copper were found in many places in Sri Lanka, and from that evidence, we can assume Rome coins were used for transactions in Sri Lanka. And many of Rome coins found in Sri Lanka are belongs to 4-5 centuries AD.[02] So that, we understood Sri Lanka had a great trade relationship with Rome at that time.

Early in the nineteenth century a pot of gold coins found from the Jaffna Peninsula, that inscribed 'ancient Greek characters, konob - obryza', probably belongs to the Byzantine period of Rome.[17] This was the first time that gold Roman coins were found in Sri Lanka. More than 2000 Roman gold coins were found from Bandagiriya and Pallemalala which have been dated to the Anuradhapura period, and also imitated gold coins found from Mirigama and Weyangoda.[41] Codrington has recorded eight Republican Silver coins (denarii) that belongs to 144 to $49 \mathrm{BC}$ but without details of where they were found.[55][65] Apart from gold and silver coins, few early Imperial coins were found from Sri Lanka with less valuable metals such as second and third brass.

Besides Roman coins, some Greek coins were also found in This publication is licensed under Creative Commons Attribution CC BY.

http://dx.doi.org/10.29322/IJSRP.11.07.2021.p11590
Sri Lanka. Codrington published about two Greek coins that belonged to the period of c.B.C. 350-250 (Acarnania, Leucas) the surface with the head of the Apollo and c.B.C. 187-175 (Seleucus IV) the surface of Diademed head.[17] Some coins were found from Jaffna that belongs to the period of 'Chandamparan Senicutti' also. And there are some special tokens found from Tissamaharama, that are similar to Greek coinage with symbols of turtle and tortoise.[11]

According to Weerakkody, both Roman and Indo-Roman coins have been circulating in South India for a considerable time before reaching Sri Lanka at the end of the fifth century.[57] Because most Roman and Indo-Roman coins are found in ports and coastal areas in the South-Western part of Sri Lanka, we can believe most commercial activities are conducted based on the wet and coastal zones in Sri Lanka. Also, this area is located close to South India, it would be a great area for the foreign trade that we mentioned earlier as South Indians sold products from East to West. There was a South Indian mercantile corporation called 'ainnurruvar' that was spread their corporation in South and South-East Asia. They have established several Tamil inscriptions in Sri Lanka about some activities. And most of them are located in the wet zone. Perhaps they were also involved in the Greco-Roman trade with Sri Lanka.

From Cosmos's records, we can understand Sri Lanka had custom officers in our ports. Also, the inscription from Devinuwara has information about the customs office in Devinuwara. So that we understood Sri Lankan trade was conducted according to international standards. Many Roman and Greek coins were found from Jaffna, and we can assume Jaffna also was a trade centre in contemporary periods but not using today. Because Jaffna is very close to South India, it must be an easy place to have trade relationships with South India also.

By the fifth century AD, Sri Lanka was one of the main trade centres in the Indian Ocean. The main reason for this was that Sri Lanka was located on the West and East trade route. From the Red Sea to the Arabian Sea, the sea voyage and the evolution in the speed of ships made the journey to Sri Lanka and beyond easy. By the time between the seventh and ninth centuries AD, the Indian Ocean had become a haven for ships from all over the world.[05][12][18][58][60] Merchants from countries such as China, Persia, Ethiopia, Java, Sumatra, Arabia, India, Rome, Malaysia, Indonesia, Burma (Myanmar) may have used Sri Lankan ports as trading centres for the exchange, sale and purchase of goods. But by the seventh century AD, the Arabs seized control of the sea trade held by the Greek and Roman merchants. As a result, Roman merchants faced competition. During the same period, the power of the Roman Empire also declined, and as a result that Roman trade also declined. In other words, the fall of Alexandria in Egypt in $638 \mathrm{AD}$, caused the end of the direct trade with Rome and the Western countries.[12] Greco-Roman trade relationship was based on only commercial purposes.[04][05][16][21][24][29][32][33][57] But other 
ISSN 2250-3153

Europeans such as Portuguese, Dutch, English and French pursued sole authority in trade and had commercial as well as religious and political objectives.

\section{Conclusion and Summary}

Sri Lanka had maritime trade relations even in the $6^{\text {th }}$ century BC. The famous 'Silk Road' created new economic ties for Sri Lanka based on commercial activities. Foreign authors have many records about Sri Lanka and Greco-Roman trade. The Foreign authors such as in this study Onecicritus of Astypaleia, Eratosthenes, Strabo, Ptolemy, Megasthenes, Cosmos, Pliny, Procopius and the author of Periplus of the Erythrean Sea were mentioned in the study and. they have mentioned the Sri Lankan trade of pearls, gems, transparent stones, muslins, tortoise shells, rice, honey, ginger, cinnamon, beryl and other metals as well as elephants. Pliny wrote about the trade delegations and embassy between Sri Lanka and Rome. Also, archaeological evidence found from ports and other places described the between Sri Lanka and GrecoRome. Because Sri Lankan trade had a close relationship with Indian trade, certain Indian factors were also important in conducting this research such as some Indian trade relationships and archaeological evidence. From Sri Lanka archaeologists found both Greek and Rome coins made from gold, silver and brass. The main archaeological evidence is Roman and Indo-Roman coins for the study of the trade relationship between Sri Lanka and Greco-Roman.

Evidence that we discussed, shows that Sri Lanka worked more closely with the Western world as the Silk Road developed due to their trade relations with China and India, with the growth of the Greek and Roman Empire. On the other hand, we understood that Sri Lanka provided some luxury commodities that reached the West from the East. This research showed that there was an internal transport system in Sri Lanka based on the Walawe river. Because of Roman coins found from many places in Sri Lanka, we assumed Roman trade was spread in many places in Sri Lanka. At some times India and Persia acted as intermediaries between Sri Lanka and Greco-Roman trade and also Sri Lanka acted as a trade centre for other mercantile countries. Most commercial activities are conducted based on the wet and coastal zones in Sri Lanka and it may be helped to connect with Indian trade also.

In conclusion, we can say that Sri Lanka was a core in the ancient trade system and by the fifth century AD, Sri Lanka was one of the main trade centres in the Indian Ocean. Finally, we can say Sri Lankan trade was conducted according to international standards.

\section{References}

[1] 1960. The Scriptores historiae augustae. Cambridge, Mass.: Harvard University Press.

[2] 2018, Purāṇayen Rupiyalaṭa, History of Currency in Sri Lanka, This publication is licensed under Creative Commons Attribution CC BY.

http://dx.doi.org/10.29322/IJSRP.11.07.2021.p11590
Department of Communication, Central Bank of Sri Lanka, Colombo.

[3] Abeydeera, Ananda 2009, New light on the first Sri Lankan Embassy to Rome mentioned by Pliny the Elder, The Sri Lanka Journal of the Humanities, Vol XXXV (1\&2), University of Peradeniya, Peradeniya.

[4] Armstrong, K., 2021. India and Sri Lanka in the time of the Roman Julio-Claudians by Keith Armstrong. [online] Academia.edu. Available at: $<$ https://www.academia.edu/3995659/India_and_Sri_Lanka_i n_the_time_of_the_Roman_Julio_Claudians_by_Keith_Armst rong $>$ [Accessed $1 \overline{6}$ May 2021].

[5] Bandaranayake, S., Devaraja, L., Silva, R., Wimalaratne, K.D.G, 2013 "Sri Lanka and the Silk Road of the sea", Sri Lanka Institute of International Relations, CCF, Sri Lanka National Commission For UNESCO.

[6] Begley, V (2004), in Ancient port of Arikamedu new excavations and researches, 1989-1992, Volume 1. Pondichéry: Centre d'histoire et d'archéologie, École française d'Extrême-Orient.

[7] Begley, V. (1983). Arikamedu Reconsidered. American Journal of Archaeology, 87 (4), 461-481. doi:10.2307/504104

[8] Begley, V. (1988). Rouletted Ware at Arikamedu: A New Approach. American Journal of Archaeology, 92 (3), 427-440. doi: $10.2307 / 505557$

[9] Berggren, J. L., Jones, A., \& Ptolemy,. (2000). Ptolemy's Geography: An annotated translation of the theoretical chapters. Princeton: Princeton University Press.

[10] Bopearachchi, O., 1990 "Some observations on roman coins found in recent excavations at Sigiriya", Ancient Ceylon No.08, p. 20.

[11] Bopearachchi, O., Falk, H., \& Wickremesinhe, R. (2000). Earliest Inscribed Coins, Moulds, Seals and Sealings from Tissamaharama (Sri Lanka). The Numismatic Chronicle (1966-), 160, 117-134. Retrieved May 16, 2021, from http://www.jstor.org/stable/42668263

[12] Bopearachchi, Osmund \& Wickremesinghe, Rajah M. 1999, Ruhuna an ancient civilization re-visited Numismatic and Archaeological evidence on inland and maritime trade, R.M. Wickremesinghe, Nugegoda.

[13] Boussac, M., Salles, J. and Yon, J., 2016. Ports of the ancient Indian Ocean. Delhi: Primus Books.

[14] Cherian, P.J., Raviprasad, G.V., Datta, K., Ray, D. K., Selvakumar, V., Shajan, K.P., 2009 'Chronology of Pattanam: A Multi-cultural Port Site on the Malabar Coast', Current Science, Vol. 97 (2), 236-40.

[15] Cherian, P.J., Selvakumar, V., Shajan, K.P, 2007, 'Evidence for the Ancient Port of Muziri at Pattanam, Kerala', Chemmozhi, Vol. 2 (1), pp. 26-27

[16] Cobb, M. 2018. Rome and the Indian Ocean trade from Augustus to the early third century CE. Leiden: Brill. https://doi.org/10.1163/9789004376571

[17] Codrington, H.W. 1924, Ceylon coins and currency, Joseph Pearson (Ed.), Colombo National Museum, Colombo 07.

[18] Coningham, R.A.E., M.J. Manuel \& J. Shoebridge. 2016. Reconstructing networks of trade and exchange in the Indian Ocean during the Early Historic period: case studies from 
Anuradhapura (Sri Lanka), in K.S. Mathew (ed.) Imperial Rome, Indian Ocean Regions and Muziris. New perspectives on maritime trade: 31-52. Abindgon: Routledge.

[19] Coningham, R.A.E., M.J. Manuel, C.E. Davis \& P. Gunawardhana. 2017. Archaeology and cosmopolitanism in Early Historic and medieval Sri Lanka, in Z. Biedermann \& A. Strathern (ed.) Sri Lanka at the crossroads of history: 19-43. London: UCL Press.

[20] Cosmas, C., 1909. Topographia christiana. Winstedt, E.O. Ed. Cambridge: Univ. Pr.

[21] Darley, R. 2017. 'Implicit cosmopolitanism' and the commercial role of ancient Lanka. In Biedermann Z. \& Strathern A. (Eds.), Sri Lanka at the Crossroads of History (pp. 44-65). London: UCL Press. doi:10.2307/j.ctt1qnw8bs.7

[22] De B. Priaulx, O. (1863). On the Indian Embassies to Rome, from the Reign of Claudius to the Death of Justinian-Continued from p. 298 of the XIXth Vol., Journ. R.A.S. Journal of the Royal Asiatic Society of Great Britain and Ireland, 20, 269-312. Retrieved May 16, 2021, from http://www.jstor.org/stable/25581251

[23] De Beauvoir Priaulx, O. (1861). On the Second Indian Embassy to Rome (Pliny, Nat. Hist. VI, 24). Journal of the Royal Asiatic Society of Great Britain and Ireland, 18, 345-361. Retrieved May 16, 2021, from http://www.jstor.org/stable/25228702

[24] De Romanis, F. 2005, 'Romanukharattha and Taprobane: Relations between Rome and Sri Lanka in the First Century AD', in De Romanis, F., Tchernia, A., eds, Crossings: Early Mediterranean Contact with India, New Delhi, pp. 41-43

[25] Dissanayake, G.U., 2017. Purāṇa śrīlamikāva vidēśa rațaval saman̆ga pævæt vū vāṇija sambandhatā piḷiban̆da aitihāsika saha purāvidyātmaka adhyayanayak, Karuna - Prof W.S Karunathilake Commeration Volume In Sinhala, S Godage and Brothers Pvt ltd. Colombo 10.

[26] Ferguson, D. (1904). The "Taprobane" of Pliny and Ptolemy. Journal of the Royal Asiatic Society of Great Britain and Ireland, 539-541. Retrieved May 16, 2021, from http://www.jstor.org/stable/25208681

[27] Fitzpatrick, M. (2011). Provincializing Rome: The Indian Ocean Trade Network and Roman Imperialism. Journal of World History, 22 (1), 27-54. Retrieved May 16, 2021, from http://www.jstor.org/stable/23011677

[28] Gaur, A.S., Muthucumarana, R., Chandraratne, W.M., Orillandeda, B.C., Manders, M., Karunarathna, S., Weerasinghe, P., Dayananda, A.M.A., Zainab, T., Sudaryadi, A., Ghani, K.A.B.A., Wahjudin, J., Samaraweera, N. 2011, Preliminary assessment of an early historic (2000 years old) shipwreck at Godawaya, Sri Lanka, Bulletin of the Australasian Institute for Maritime Archaeology,

[29] Gurukkal, R. (2013) 'Classical Indo-Roman Trade: A Historiographical Reconsideration', Indian Historical Review, 40 (2), pp. 181-206. DOI: 10.1177/0376983613499670.

[30] Huntingford, G. and Agatharchides., 2016. The Periplus of the Erythraean Sea. London: Routledge.

[31] Internet Archive. 2021. Cosmoarabhia : Ptolemv, 2nd cent: Free Download. Borrow. and Streamina: Internet Archive. 「online1 Available <httDs://archive.org/details/cosmographia0 Optol>.

This publication is licensed under Creative Commons Attribution CC BY.

http://dx.doi.org/10.29322/IJSRP.11.07.2021.p11590
[32] Jayasuriya, C. (1949). A Historical Survey of Ceylon Trade. Journal of the Royal Society of Arts, 97 (4802), 757-768. Retrieved May 16, 2021, from http://www.jstor.org/stable/41363924

[33] Jayasuriya, C.E.P. 1949, A historical survey of Ceylon trade, Journal of the Royal Society of Arts, Vol 97, No.4802, Royal Society for the Encouragement of Arts, Manufactures and Commerce.

[34] Kingwell-Banham, E., Bohingamuwa, W., Perera, N., Adikari, G., Crowther, A., Fuller, D., \& Boivin, N. 2018. Spice and rice: Pepper, cloves and everyday cereal foods at the ancient port of Mantai, Sri Lanka. Antiquity, 92(366), 1552-1570. doi:10.15184/aqy.2018.168

[35] Lawler, A. (2014). Seafaring in Ancient Sri Lanka. Archaeology, 67 (6), 42-47. Retrieved May 16, 2021, from http://www.jstor.org/stable/24364646

[36] Lawler, Andrew 2014, Seafaring in ancient Sri Lanka, Archaeology, Vol 67, Archaeological Institute of America.

[37] Mahavasha In Sinhala, 2012, Sri Sumangala Thero, Hikkaduwe \& Batuwantudawe (ed), Department of National Museums, Sri Lanka.

[38] McLaughlin, R. (2014). Ancient Contacts: The Roman Emperor and the Sinhalese King. Classics Ireland, 21-22, 1-40. Retrieved May 16, 2021, from http://www.jstor.org/stable/26246545

[39] Meredith, D. (1953). Annius Plocamus: Two Inscriptions from the Berenice Road. The Journal of Roman Studies, 43, 38-40. doi: $10.2307 / 297778$

[40] Müller, K., 1990. Geographi Graeci minors. Hildesheim: G. Olms.

[41] Munasinghe, D.S.A., Fernando, D.C.V. 2016, Trading Relationships between ancient Sri Lanka and ancient Greek and Rome, Oracle, Vol VII, No 01. Department of Western Classical Culture, University of Kelaniya. pp 35-37.

[42] Muthucumarana, Rasika., Gaur, A.S., Rao, B.R., Chandraratne, W.M., Manders, M., Dayananda, A.M.A., Khedekar, V.D. \& Bhushan, Ravi, 2014, An early historic assemblage offshore of Godawaya, Sri Lanka: Evidence for early regional seafaring of South Asia, Journal of Maritime Archaeology Vol 9, No 1, Springer. https://www.researchgate.net/publication/261016208

[43] Ovid. Tristia. Ex Ponto. Translated by A. L. Wheeler. Revised by G. P. Goold. Loeb Classical Library 151. Cambridge, MA: Harvard University Press, 1924.

[44] Peris, Merlin. 2006, Greeks in the Mahavamsa, The Sri Lanka Journal of the Humanities, Vol XXXII (1\&2), University of Peradeniya, Peradeniya.

[45] Pliny, 2010. Naturalis historia. Turnhout: Brepols Publishers.

[46] Ravitchandirane, P. (2007). Stratigraphy and Structural Context of Arikamedu. East and West, 57 (1/4), 205-233. Retrieved May 17, 2021, from http://www.jstor.org/stable/29757729

[47] Researchomnia, 2016, Roman Commerce with Ceylon \& Beyond http://researchomnia.blogspot.com/2016/09/romancommerce-with-ceylon-surrounding.html? $\mathrm{m}=1$

[48] Seland, E. (2014). Archaeology of Trade in the Western Indian Ocean, 300 BC-AD 700. Journal of Archaeological Research, 22 (4), 367-402. Retrieved May 17, 2021, from 
http://www.jstor.org/stable/24018067

[49] Selvakumar, V..., 'Trial excavations at Pattanam, Paravur Taluk, Ernakulam District, Kerala-A Preliminary Report', Journal of the Centre for Heritage Studies, Vol. 2, 2005, 57-66.

[50] Wansaththappakasini In Sinhala , Amarawansha Thero, Akuratiye

[51] Weerakkodi, D.P.M., 1981. Ancient Sri Lanka as Described by Cosmas, The Sri Lanka Journal of the Humanities, vol. vii, no. $1 \& 2$, University of Peradeniya, pp.107-127

[52] Weerakkodi, D.P.M., 1989. Sri Lanka as known to Strabo, Sri Lanka Journal of Humanities vol. XV, University of Peradeniya. pp 55-64

[53] Weerakkodi, D.P.M., 1990. The note on the Greek names for Sri Lanka, Sri Lanka Journal of Humanities vol. XVI, University of Peradeniya, pp 118-130

[54] Weerakkodi, D.P.M., 1993. Pliny's Influence on Later Latin Notices of Sri Lanka, The Sri Lanka Journal of the Humanities, vol. xix, no. $1 \&$ 2, University of Peradeniya, pp.27-33

[55] Weerakkodi, D.P.M., 1995. Roman Coins of Sri Lanka: Some Observations, The Sri Lanka Journal of the Humanities, vol. xxi, no. $1 \& 2$, University of Peradeniya, pp. 1-30

[56] Weerakkodi: in "Roman Coins of Sri Lanka: Some Observations", The Sri Lanka Journal of the Humanities, (1995), p. $1-30$

[57] Weerakkody, D.P.M. 1997, Taprobane - Ancient Sri Lanka as known to Greeks and Romans, BREPOLS, Turnhout.

[58] Bouzek, J. (ed.), 1993. Ceylon Between East and West. Anuradhapura Abhayagiri Vihara 1981-1984. Excavations and Studies. Prague.

\section{AUTHORS}

First Author 01 - Dr Mangala Katugamppola, B.A., (Kelaniya), PG Dip. (PGIAR), M.Phil. (Kelaniya), Ph.D. (china)

MSLCA, Head of Department, Department of Archaeology, University of Kelaniya, Srilal@kln.ac.lk

First Author 01 - D.S.A Munasinghe, B.A. (Kel'ya), DPPB (PGIAR), DPZA (PGIAR) Red, MSc (PGIAR) Red., Assistant Lecturer, Department of Archaeology, University of Kelaniya, dsamunas 2019@kln.ac.lk

Second Author - Kaveesha Nanayakkara, B.A. (Kel'ya), DPPB (PGIAR) Red, Department of Archaeology, University of Kelaniya, kaveeshananayakkara1995@gmail.com

Third Author - D.C.V Fernando, B.A. (Kel'ya), MPhil (P'deniya) Red., Assistant Lecturer, Image Art \& Drama \& Theatre Unit, Department of Fine Arts, University of Kelaniya, chathurav2019@kln.ac.lk

Fourth Author - K.K.P.M Jayathilake, B.A. (Kel'ya), PG Dip (PGIAR) Red, Assistant Lecturer, Department of Archaeology, University of Kelaniya, kkpmjaya 2019@kln.ac.lk

Correspondence Author - D.S.A Munasinghe, B.A. (Kel'ya),
[59] Bouzek, J., Deraniyagala, S. U. 1985 Tessons de vases Hellénistiques trouvés en Sri Lanka. In: Bulletin de Correspondance Hellénique 109: 589-596.

[60] Carswell, J. Deraniyagala, S.U and Graham, A. 2013.Mantai. City by the Sea, Linden Soft Verlag. Hb., ISBN-13: 9783929290394.

[61] Schenk, H.2001, The Development of Pottery at Tissamaharama. In: Weisshaar, H.-J. Roth, H. Wijeyapala, W. (eds.), Ancient Ruhuna. Sri Lankan - German Archaeological Project in the Southern Province Vol. 1. (= Materialien zur Allgemeinen und Vergleichenden Archäologie 58), pp. 59-195. Mainz.

[62] Silva R.1985, Mantai - a second Arikamedu? In: Antiquity.59: 46-47.

[63] Walburg, R. 1991, Late Roman Copper Coins from Southern India. In: Jha, A. K. (ed.), Coinage, Trade and Economy, January 8th-11th, 1991, $3^{\text {rd }}$ International Colloquium. Indian Institute of Research in Numismatic Studies, pp. 164-167. Bombay.

[64] Walburg, R. 2008 Coins and Tokens from Ancient Ceylon. In: Weisshaar, H-J./Dissanayake, S. (eds.), Ancient Ruhuna. Sri Lankan - German Archaeological Project in the Southern Province, Vol. 2. (= Forschungen zur Archäologie Außereuropäischer Kulturen 5). Wiesbaden.

[65] Banham, Eleanor Kingwell., Bohingamuwa, Wijerathne., Perera, Nimal., Adikari, Gamini., Crowther, Alison., Fuller, Dorian Q \& Boivin, Nicole,2018, Spice and rice: pepper, cloves and everyday cereal foods at the ancient port of Mantai, Sri Lanka, Antiquity Publications Ltd.

DPPB (PGIAR), DPZA (PGIAR) Red, MSc (PGIAR) Red., Assistant Lecturer, Department of Archaeology, University of Kelaniya, dsamunas 2019@kln.ac.lk 